\title{
Eco-phenomenology in the local concept of Buginese agriculture based on Kutika manuscript
}

\author{
Rahmatia $^{1 *}$ and Tommy Christomy ${ }^{1}$ \\ ${ }^{1}$ Faculty of Humanity, Universitas Indonesia, Depok, 16424, Indonesia.
}

\begin{abstract}
The way Bugis people adapt to nature has been contained in the book of Lontara', which is called Kutika. Kutika's scriptwriting background was full of philosophies and religious influences when the script was created. The philosophical calculation time shows how Buginese humans talk to nature, read signs, and treat nature as an equal element, not as an object. This philosophical triggered the writer to see it from ecophenomenology by Saras Dewi and Heidegger's perspective. This research applies a philological approach with a critical edition method to translate the manuscript, then linking text analysis with eco- phenomenology. Through the eco-phenomenology approach, local concepts in the Kutika text regarding the use of natural pesticides (biopesticides) can be described. Eco-phenomenology views humans and nature as equal entities. This is in line with the Bugis perspective, which views pests not as the enemy but as friends who should be fed first. Lontara' Kutika shows that since hundreds of years ago, the Bugis people have had modern agriculture techniques with their local knowledge. The knowledge that is considered ancient is needed as an alternative to solve environmental problems today.
\end{abstract}

\section{Introduction}

In the global view, the Bugis are synonymous with the sea and maritime activities. This assumption only represents the Bugis, who inhabit coastal areas such as Bajo, Pare-Pare, North Sinjai, and Bulukumba [1]. Not many realize that apart from fishermen, the Bugis are also farmers and have skills in cultivating rice fields, such as Sidenreng, Pinrang, and Wajo' [2]. In fact, in 1971 South Sulawesi became one of Indonesia's rice barns with 1,683,000 tons of dry rice [2]. Quoting Pelras's statement [1] in his writings, confidently said that the Bugis were farmers. Their maritime activity did not really develop until the 18 th century AD after massive emigration from South Sulawesi. Since before Christ, they have managed various kinds of agricultural products such as iron, copper, gold, sandalwood, rattan, and grains, including agricultural products such as rice, which is the main product [1]. Other agricultural products are plantation products in coconut and coffee, which are export commodities [2].

\footnotetext{
* Corresponding author: rahmalogi@gmail.com
} 
This opinion is in line with Andaya [3], who says that rice is life for the Bugis. The importance of rice as the primary food has resulted in several traditional practices that pay high respect to the Goddess of Rice. In Sinrili'Kappala Tallumbatua, which tells about episodes of war [4], it is seen that no matter how serious the war is, one should not rule out the importance of maintaining the security of the rice fields. The people of South Sulawesi respect the Goddess of Rice so much that they dare not make her angry by destroying the rice plants. So hard is this goddess's character that the special knife (rakkapeng) for harvesting is made as small as possible to hide behind the palm of the hand so as not to offend the Goddess of Rice. The massure' Lontara' Meong Mpaloé tradition is a sacred ceremony that can only be recited during rituals of preparation for planting rice (Mappalili), planting rice seeds (Maddoja Biné), or harvesting rice (Mappadéndang) [5]. This ceremony is a form of respect for the Bugis people towards rice and the Goddess of Rice called Sangiangserri [1].

The tradition of respecting rice is proof that the Bugis people always maintain a balanced relationship between humans and nature. Since hundreds of years ago, the Bugis people have known in terms of seeing nature. The knowledge is obtained by always rely on natural phenomena. By observing natural phenomena, they recorded their experiences in a book called Lontara. Lontara' that gives clues to the time is called kutika [6]; kotika [7]; or pau kotika [2]. When referring to the initial period of research on kutika, in 1868, B.F. Matthes has searched Lontara' Kutika and described the tables that explain the day's directions. One hundred thirty years later, kutika was reintroduced by Kathryn Robinson in 1998 and continued by Roger Tol [6]. In his writing, Tol explained the 20 names of days in Kutika Bilangeng Duappulo, the count of good days and bad days in carrying out a wedding ceremony. His latest research on kutika [8] describes three amulets in the British Library collection from Bone's kingdom in 1814 AD. The three amulets are kutika diagrams for determining planting time based on animal days.

In the following period, research on the kutika text as the Buginese local calculating method has been studied through several approaches. First, the science approach [9]. The study compared the month calculating method between the pananrang (kutika) in Lontara' and the Hijri calendar. The study's conclusion shows that the difference in determining the month's start is due to different concepts and criteria regarding the new moon. Therefore, it is necessary to have the criteria of imkân alru'yah as criteria for Indonesian reckoning that has been agreed by all parties. Second, research on kutika has also been studied through the field of cultural linguistics [10]. Through a linguistic-cultural approach, the research explains the symbols of good and bad days in Lontara Pananrang. In the Lontara Pananrang, there is a counting guideline called kutika or a list of good and bad days. Good and bad symbols are illustrated through animal types, time symbols, mathematical symbols, and constellations symbols. Third, kutika research through historical and ethnographic approaches [11]. The writing comprehensively provides a good explanation regarding the day counting system or the Bugis calendar based on the kutika script. Besides, in terms of ethnographic research, it is concluded that the use of time calculations in the Bugis community is not only for worship but also for agricultural activities, sailing navigation, and weather forecast.

Departing from the study of philology, this paper describes the forms of local knowledge possessed by the Bugis in agriculture through the Kutika script. The ecophenomenology approach is an attempt to describe the way Bugis humans talk to nature. For the first time, this study links two different themes into a single, interconnected unit. The Kutika manuscript, which has been limited to determining good and bad days, has entered a new, more fundamental area on a philosophical level. This philosophical aspect cannot be separated from the development of religious understanding when this manuscript was written. Broadly speaking, efforts in opening the access to manuscripts are not only at 
the level of description but also to break down the role of an ancient manuscript into an applicable science to solve contemporary problems, especially in agriculture.

\section{Method}

This research's corpus is a manuscript that comes from the Mulawarman Museum collection in East Kalimantan, with the title "Kutika Ugi' Sakke Rupa" (KUSR). Kutika is a manuscript that contains the tradition of days calculation among the Buginese community. Generally, Kutika is defined as a collection of good and bad time records to carry out activities. This manuscript collects various counting methods and has a multi-character script written using four characters with four varied languages, i.e., Bugis, Malay, Arabic, and Banjar.

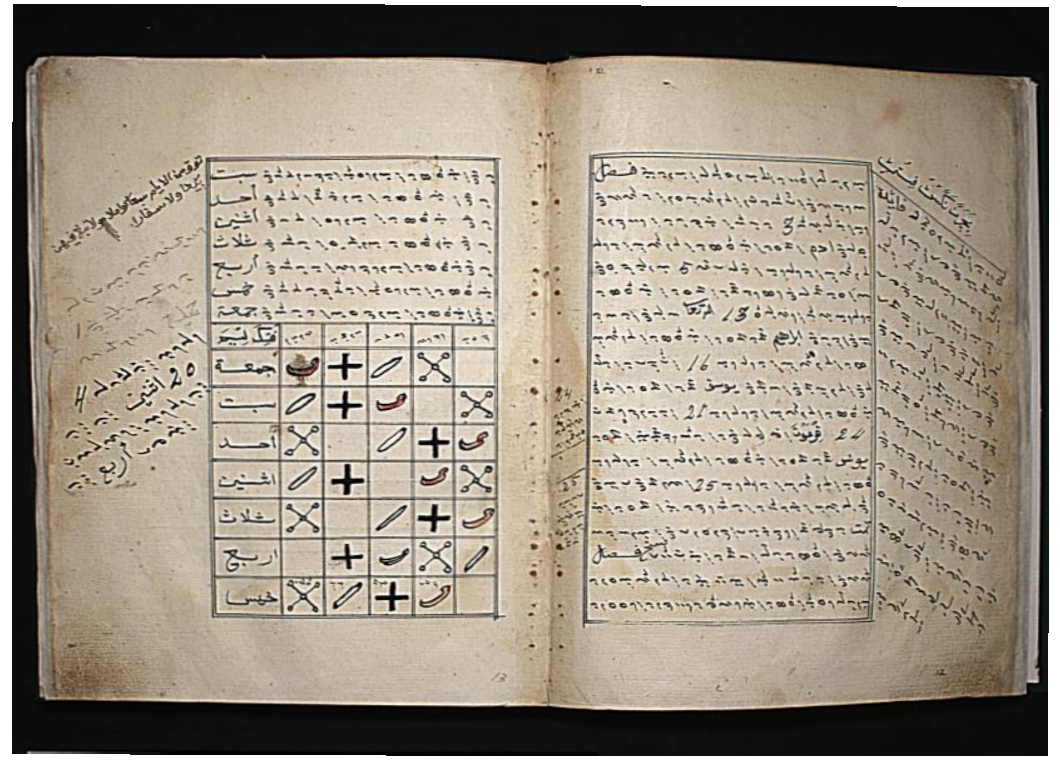

Fig. 1. The digitalized version of KUSR page 8-9 [22]

The manuscript with code MMK 1530 is 138 pages and contains several methods of calculating days and times. However, this paper will focus on one calculation system for determining planting time in agricultural activities, namely, Putika Pa'kulu Jangé. This research applies a philological approach with a critical edition method to open the manuscript access. The philological method used to translate the Kutika manuscript's text to explain Buginese agriculture's local concept. That local concept shows how Buginese talk to nature, read signs, and treat nature as an equal element, not as an object. This triggered us to see it from an eco-phenomenology perspective. The eco-phenomenological approach is used to connecting a local concept and environmental awareness in Buginese agriculture. That method is the study's scope to describe the use of biopesticides in ancient manuscriptbased agricultural techniques of the Bugis community.

Phenomenology is one of the philosophical methods that study the relationship between subject and object. Environmental phenomenology is an effort to understand ecosystems as a phenomenon that has intentionality between its subject and object. In other words, ecophenomenology sees humans as an entity that is inseparable from nature [12]. This is closely related to how Bugis humans communicate with nature to coexist in harmony based on the KUSR script. The eco-phenomenology approach in this study relies on Heidegger's ontological relationship regarding human ethical attitudes to his world [21]. Heidegger 
elaborates on three definitions, which are building, living, and thinking. Those three things are the main human activities. In terms of living, according to Heidegger, it can be used as a guide for the ideal way of living side by side with nature. A settler builds his culture, technology, and all social systems in accordance with his ecosystem.

According to Heidegger, living is not just a concept about a house, a bridge, offices, a mine, or an area of activity. Living is a matter of humans maintaining the peace of their environment, preserving their nature and adjusting their activities, and applying technology [21]. Eco-phenomenology is an appropriate point of view in seeing and reformulating the relationship between humans and nature. Eco-phenomenology means understanding ecosystems as phenomena, not as objects separated from the subject, but phenomena that require intentionality between the subject and the object [12]. But one thing that should underline in this paper is the Kutika manuscripts, which is the reference for textual analysis, which has been influenced by Sufism. This means that nature, which has a soul, does not mean that nature is treated as a human being, but rather understands that what is taken from nature will be returned in another form of life.

\section{Results and discussion}

\subsection{Buginese local knowledge in agricultural techniques based on KUSR manuscripts}

Kutika Ugi' Sakke Rupa (KUSR) is a book of time calculations created by the Bugis as a guide in their daily activities. Based on the text's colophon, the KUSR manuscript was completed in $1311 \mathrm{H}$ or $1893 \mathrm{AD}$. This is factual data that 127 years ago, the Bugis knew calculating the time equivalent to the Javanese and the Malay people. In fact, it has been integrated with Arabic and Chinese traditions. One of the calculation methods in the KUSR that will be analyzed in this section is Putika Pukulu' Jangé, hereinafter abbreviated as PPJ. PPJ also known as 'waktu tujuh', is a time counting system based on seven-time hour change. You can refer to the following picture from trancription of KUSR text to see the timetable. In that picture, the time sequence starts from Syamsu-Zahrah-Attarid-QamarZuhal-Mustarih-Mareh followed by the day at the top and the time on the right side. The seven times rotate every 7 hours and alternate every 1 hour in a day. 


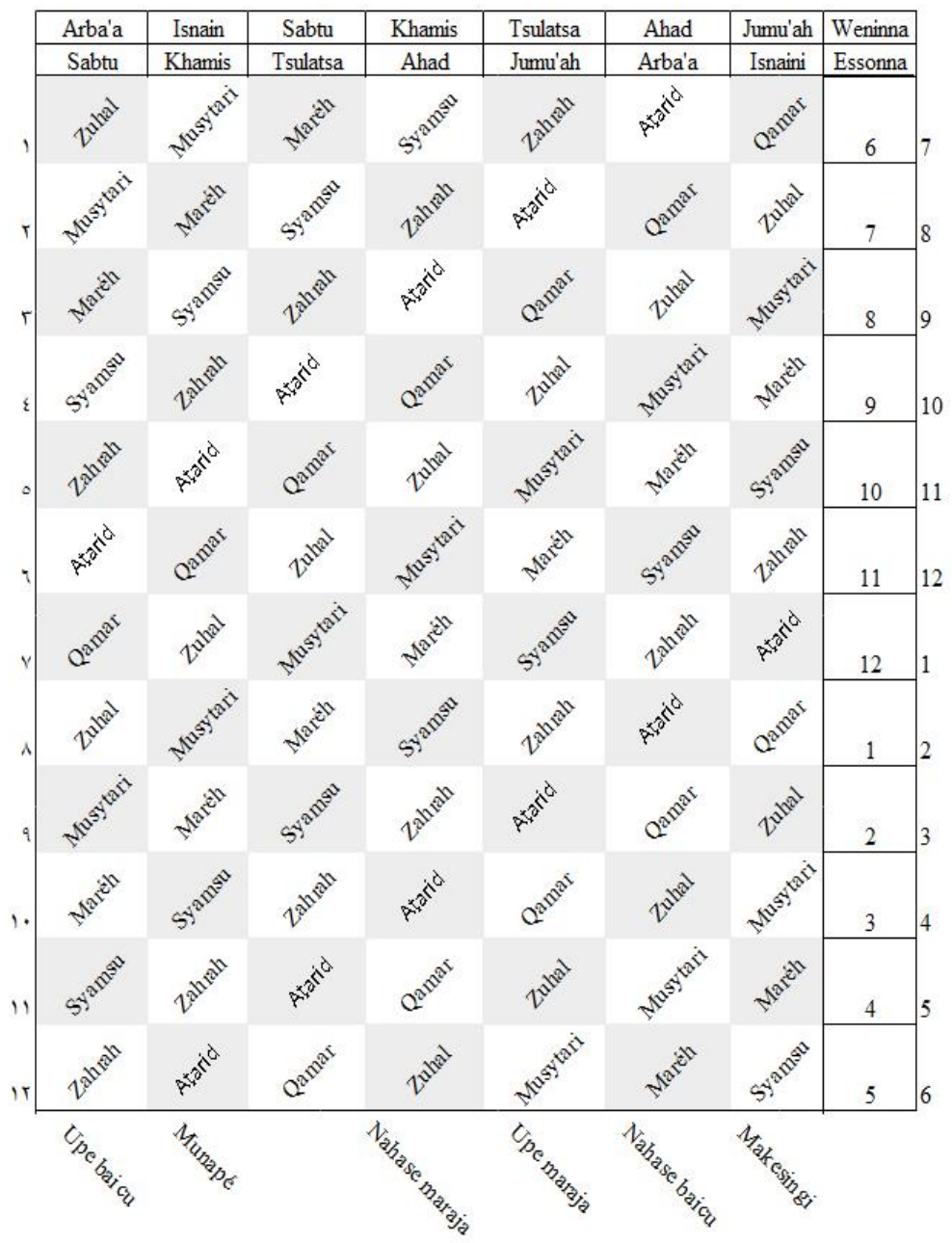

Fig. 2. Change of time in PPJ [13]

Agricultural activities are closely related to the use of fertilizers and pesticides, which are mostly chemical-based. The use of chemical fertilizers and pesticides can cause poisoning or damage to plants if they exceed the prescribed dosage. The use of chemical fertilizers has been associated with high levels of nitrate in groundwater, which causes hypoxia in aquatic ecosystems and the contamination of drinking water sources [14]. Therefore, the green revolution movement or back to nature began to be echoed in the agricultural sector to restore natural sustainability. The movement back to using natural products in the manufacture of fertilizers and pesticides is a method that has been used for a long time. The method is also included in the KUSR text, which explains organic fertilizers and biopesticides or vegetable pesticides.

The sentence, "tarona bérowangé" which means save for pests, indicates that pests are not killed in that cultivation technique but are fed first. Food provided for pests is oyster skin, tamarind, and star fruit. This is done so that pests do not eat coconut seeds and cause crop failure. The main advantage of using vegetable pesticides in agriculture is to protect the ecosystem because it does not leave residues (biodegradable). Besides, vegetable pesticides can reduce the risk of humans being exposed to chemicals attached to plants and maintain the survival of organisms that are needed to fertilize the soil. Therefore, vegetable 
pesticides are an alternative for pest control that meets the concept of Integrated Pest Management (IPM) [15].

The use of organic fertilizers has also been mentioned in the KUSR text, namely the use of alosi (areca nut) and barrelé (maize) as the basis for planting before the coconut seeds are introduced. The use of the sentence 'rimula mo $(\mathrm{m})$ po'na narapi $5^{\prime}$ can be interpreted as the first fruit that grows is the best seed to be replanted as well as to function as fertilizer. This traditional knowledge can be explained scientifically through the coconut fruit content. The first coconut fruiting on the tree means that this fruit is riper than the others. So that it is faster to decompose. Rotten fruit contains more Nitrogen (N), Phosphorus (P), Potassium (K), Vitamins, Calcium (Ca), Iron (Fe), Sodium (Na), Magnesium (Mg). This substance is beneficial for soil fertility. In modern agricultural science, rotten fruit waste is processed into liquid organic fertilizer (LOF) [16].

\subsection{Ecophenomenology in the Buginese agriculture}

In KUSR, the kutika text is closely related to traditional calculation science and environmental conservation. Traditional calculation science in KUSR serves to find out how Bugis people see nature. The KUSR text's role as a guideline for environmental preservation can be examined through agricultural techniques revealed in the KUSR text, i. organic fertilizers and biopesticides. Through the quotations in table 1, it can be seen that Buginese agricultural science has recognized vegetable pesticides derived from oyster shells, tamarind, and star fruit to control pests. This control method is a legacy of knowledge from Bugis ancestors, which comes from life experiences and local wisdom. This knowledge was passed down orally and then outlined in the book called Lontara' to become a guide for their descendant. It is related to the Putika Pa'kulu Jange or PPJ table. Wednesday afternoon 3 to $5 \mathrm{pm}$ range is included in Mustarih time, which is the best time for any activity.

Table 1. Quotation from KUSR Text

\begin{tabular}{|c|c|c|}
\hline & Biopesticides & Organic Fertilizers \\
\hline transcription & $\begin{array}{l}\text { Pasal panessaengngi sara'na narékko tanengki } \\
\text { kaluku namasita mabuwa/ alosi mature macalae } \\
\text { dé'pa e(ng)ka madunu nariyalapikang sibawa } \\
\text { barelé si'di burutta pe(n)re malonjo/ aja' } \\
\text { namala mukirakira sipuwéni kalukué ileme/ } \\
\text { narékko itanémi tettu da(n)rappe naripasitetung } \\
\text { agatuna palédota waliwali makai uluta } \\
\text { so(ng)kangino riyalebbona/ \{iyanaé\} sara'na } \\
\text { aja' na(n)réi berawa ilapi'i uli' tireng sibawa } \\
\text { cempaga bayinatto tarona bérowangé// } \\
\text { KUSR pp. } 54 \text { [13] }\end{array}$ & $\begin{array}{l}\text { ipapoléyangi ritu } \\
\text { buwana } \\
\text { gangkana(n)réna naéya } \\
\text { makesingé ri yatanengé } \\
\text { riyabalukeng rimula } \\
\text { mo(m)po'na narapi 5/ } \\
\text { KUSR pp. 72B [13] }\end{array}$ \\
\hline translation & $\begin{array}{l}\text { Pasal that explains the conditions for planting } \\
\text { coconut so that it will bear fruit quickly/ take } \\
\text { the red betel nut that has not fallen yet and } \\
\text { placed it below with the corn that grows from } \\
\text { the first stalk/ there is no need to count (the } \\
\text { number), only about half of the coconuts are } \\
\text { planted/ If you are going to plant, sit tight then } \\
\text { touch both wrists and lift them both (corn and } \\
\text { areca nut) and keep your head down as you }\end{array}$ & $\begin{array}{l}\text { when (coconut trees) } \\
\text { produce fruit that can } \\
\text { be enjoyed, then what } \\
\text { is good for planting } \\
\text { and reselling is the first } \\
\text { fruit that comes out } \\
\text { that can be reached by } \\
\text { hand/ }\end{array}$ \\
\hline
\end{tabular}


place them/ as for the condition so that it is not eaten by pests, cover it with oyster skin with tamarind and star fruit, save it for pests//

The next quotation in table 2 illustrates how the Buginese talk to nature. This perspective is correlated with eco-phenomenology, which sees nature not as an object but as an equal entity [12]. This is also related to the Buginese belief that nature has a soul and must be respected. Matalunru is the name for the soil that is mentioned in the ritual before planting. This is related to the existence of Rijäl al-Ghayb which is also described in the KUSR text. In Al-Arabi [17] seven imams nicknamed Al-Abdāl (successor) guard the seven climatic regions. If one of them dies, it will be replaced by one of the 40 people under him. Then one of the 300 people under him fulfilled those 40 people. All of these people are called Rijäl al-Ghayb, or wali whom Allah hides from human sight.

The existence of Rijäl al-Ghayb in Bugis Sufism is related to the nature of the spirit at the time of human creation. The self-concept understood by the Bugis is that human nature begins with the formation of the body and spirit. However, human reality is the spirit. In this case, the spirit is understood as an entity that does not know death. Therefore, the Bugis still believe that their ancestors can communicate with them through selected descendants. This belief is based on the eschatological journey of the Prophet Muhammad, through the event of Isra 'Mi'raj [18]. The Prophet's journey to meet his predecessor prophets and communicate with them is the basis for the possibility of humans establishing a relationship with the spirit realm from this world. Through quranic perspective and reasoning, the concept of Rijäl al-Ghayb has been believed by the Bugis for a long time.

Table 2. Nature has a soul

\begin{tabular}{|l|l|}
\hline Trancription & $\begin{array}{l}\text { narékkoto mappamula mataneng agiagi wettu asarappi tabéréselengini } \\
\text { tanaé/ nayi asenna tanaé ye matalu(n)ru jakaiwi tanengtanengku/ ibacattoi } \\
\text { patéha nabi Iliyase sibawa nabi Hédéré/ taita tanengtanengta taita rigiii } \\
\text { nale(m)pona// }\end{array}$ \\
(KUSR pp.73A [13]
\end{tabular}

The understanding that is laden with Islamic nuances in the concept of Bugis thought is a manifestation of a transitional period when traditional religious values come into contact with Islam. Many legacies of specific elements from the past Bugis culture are still alive today [19]. The KUSR text contents can be related to the Khalwatiyah Samaniyah order, which developed in the 18th to 19th centuries in South Sulawesi and Kalimantan [20]. This period is the same as when the KUSR manuscript was written or copied, namely the 19th century.

The existence of Rijāl al-Ghayb in the concept of Bugis thought can be categorized as the concept of the transcendent world in Heidegger's reflection [12]. Through the example of Rijäl al-Ghayb, Heidegger wants to show that all objects in the world have their own place, such as paying attention to the direction of the coming of Rijal al-Ghayb. Every object that appears in front of the subject has a readiness to use. The character of the object 
is the totality of the subject's world, which can only be known if it is experiencing and interacting. Heidegger argues that world transcendence is the ontological condition of a subject that can interact with the world even though the realm is foreign. Heidegger's concept of transcendence considers nature a part of the world of subjects with its own value. That value can only be revealed when the subject is involved with nature. In that sense, as long as the subject does not shut down from real knowledge of nature.

Traditional knowledge in agriculture in the KUSR text has an essential role in overcoming environmental problems. Apart from the use of natural pesticides, the KUSR text also reveals organic fertilizer techniques derived from the first grown fruit. This shows that the Bugis has modern techniques in agriculture. In looking at the realm of their world, the Bugis appreciate another entity that they call Rijāl al-Ghayb. Although this understanding has been mixed with Islamic Sufism values in the Khalwatiyah Samaniyah order, the Bugis perspective on Rijäl al-Ghayb has taken root into a local experience. The existence of Rijäl al-Ghayb and how the KUSR text describes ethics in dealing with it is in line with Heidegger's ontological relationship in Saras Dewi's Eco-phenomenology concept.

\section{Conclusion}

As mentioned in the research method, this paper only analyzes the Kutika manuscript from the Mulawarman Museum collection, entitled Kutika Ugi' Sakke Rupa (KUSR). Therefore, this study in particular. However, the research results mentioned above show the critical role of the KUSR text contents in describing agricultural techniques and local understandings applicable in the broader life order. The knowledge that comes from hundreds of years ago is needed as an alternative to solve today's environmental problems. This is very relevant to environmental awareness in agriculture, which is re-using biopesticides and natural fertilizers.

For further studies, it is hoped that there will be a different approach to parsing classical texts' contribution to environmental issues. It should be noted that this study aims to open up a space for discussion if it is too much to be said that this paper is the first research to utilize the contents of the Kutika manuscript in environmental science. Likewise, in further research, there is a collaboration between ecologists and philologists to obtain more scientific results.

\section{Acknowledgements}

The authors would like to express their sincere thanks for supporting this research by providing funding through the International Indexed Publications (PUTI, Publikasi Terindeks International) program with contract number NKB1249/UN2.RST/HKP.05.00/2020 from Universitas Indonesia.

\section{References}

1. Pelras, Christian, Manusia Bugis (Nalar in association EFEO, Jakarta-Paris, 2006)

2. Mattulada, Latoa : Satu Lukisan Analitis terhadap Antropologi Politik Orang Bugis (Hasanuddin University Press, Ujung Pandang, 1995)

3. Andaya, Leonard Y, Warisan Arung Palakka: Sejarah Sulawesi Selatan Abad ke-17 (Ininawa, Makassar, 2004)

4. Arif, Aburaerah dan Hakim, Zainuddin, Sinrilikna Kappalak Tallumbatua (Yayasan Obor, Jakarta, 1993) 
5. Rahman, Nurhayati, Kearifan Lingkungan Hidup Manusia Bugis berdasarkan Naskah Méong Mpaloé, (La Galigo Press, Makassar, 2009)

6. Tol, Roger, Rolled up Bugis Stories: Marriage Advice and The Tale of The Parakeet in Review of Indonesian and Malaysian Affairs, 43, 189 (2009)

7. Matthes, B.F, Makassarsche en Boeginesche Kotika's (Sutherland, Leiden University Libraries, 1868)

8. Tol, Roger, Animal days: three Bugis Amulets in British ollections, British Library official page (2020) https://blogs.bl.uk/asian-and-african/2020/04/

9. Yusmar, Syarifuddin, Penanggalan Bugis-Makassar dalam Penentuan Awal Bulan Kamariah Menurut Syariah dan Sains, Jurnal Hunafa, 5, 265 (2008)

10. Gunawan, Fahmi, Good and Teribble Days Symbols in Pananrang Manuscript: A Cultural Linguistics Approach, in Proceedings 2nd International Seminar on Linguistics (ISOL II), Universitas Andalas, Padang (2015)

11. Hasanah, N. dan Suriamihardja, Astronomy in Buginese-Makassarese Culture Based on Historical and Ethnographical Sources, in International Symposium on Sun, Earth, and Life (ISSEL), Journal of Physics, IOP Publishing (2016)

12. Saras Dewi, Luh Gede Saraswati Putri, Ekofenomenologi: Mengurai Disekuilibrium Relasi Manusia dengan Alam (CV. Marjin Kiri, Tangerang Selatan, 2018)

13. Rahmatia, A.W, Kutika Suku Bugis di Kalimantan Timur: Kajian Filologi dan Gagasan Ekofenomenologi (Thesis, Faculty of Humanity, Depok, Universitas Indonesia 2020)

14. Nolan, B. T., et.all, Probability of Nitrate Contamination of Recently Recharged Groundwaters in the Conterminous United States, Environmental Science \& Technology, 36, 2138 (2002)

15. Utami, Sri \& Haneda, Noor F, Pemanfaatan Etnobotani dari Hutan Tropis Bengkulu sebagai Pestisida Nabati, JMHT, XVI, 143 (2010)

16. Nur, Muhammad, Analisis Potensi Limbah Buah-buahan Sebagai Pupuk Organik Cair, in Seminar Nasional Teknik Industri, Universitas Gadjah Mada, Yogyakarta (2019)

17. Ibn al-'Arabi, Muhyiddin, Al-Futuhat Al-Makkiyah Jilid II [trans. Harun Nur Rosyid] (Darul Futuhat, Yogyakarta, 2018)

18. Van der Meij, Th.C, N. Lambooij, The Malay Hikayat Mi'raj Nabi Muhammad: The Prophet Muhammad's Nocturnal Journey to Heaven and Hell, (BRILL, Leiden, 2014)

19. Paeni, Mukhlis, Membaca Manusia Bugis-Makassar. (CV. Gisna Multi Mandiri, Yogyakarta, 2014)

20. Azra, Azyumardi, Jaringan Ulama Timur Tengah dan Kepulauan Nusantara Abad XVII dan XVIII Akar Pembaruan Islam Indonesia (Prenada media Group, Depok, 2018)

21. Heidegger, Martin, Being and Time (Basil Balcwell, Oxford, 1973)

22. Pudjiastuti, Titik. Digitalized Manuscript in Sumber-Sumber Tertulis Indonesia Tengah, Kajian Kodikologis, Filologis, Linguistis, Historis, dan Budaya: Kalimantan Timur dan Utara (to be published) 